\title{
MORPHOMETRIC ANALYSIS OF INFRA- ORBITAL FORAMEN IN DRY HUMAN SKULLS IN NORTH KARNATAKA REGION
}

\author{
Archana N Kotli ${ }^{* 1}$, Sangeeta S Patil $* 2$. \\ ${ }^{* 1}$ Assistant Professor, Department of Anatomy, Mahadevappa Rampure Medical College, Kalaburgi, \\ Karnataka, India. \\ ${ }^{2}$ Assistant Professor, Department of Anatomy, Mahadevappa Rampure Medical College, Kalaburgi, \\ Karnataka, India.
}

\section{ABSTRACT}

Background: Maxillary bones constitute the front of face and upper jaw. The orbital surface is marked by the ridge of bone which form the lower and inner half of the orbital opening. Just below the outer part of this ridge is the infra-orbital foramen through which the infra-orbital branch of the second division of $5^{\text {th }}$ cranial nerve passes to the skin of the face. The present study was conducted to know the precise location of Infra- orbital foramen in dry human skulls in North Karnataka region.

Materials and Methods: Fifty dry adult human skulls of unknown age and sex were examined at the Department Of Anatomy, Mahadevappa Rampure Medical college, Kalaburgi. Both sides of skull were assessed by inspection. Following certain inclusion and exclusion criteria, total foramen studied were 100 . The shape, direction, diameters and orientation of the foramen with respect to upper teeth was noted.Distance of IOF from IOM, PA and UAM were recorded.The measurements were carried out using Vernier calipers. Data collected was subjected to various statistical analysis.

Results: Majority of IOF's were Oval in shape and many were vertically oval. Most of the foramen were directed Infero- medially, rest of them were directed vertically downwards. IOF in many skulls were present at the level of $2^{\text {nd }}$ premolar. Mean value of distance of IOF from IOM is $6.6 \mathrm{~mm}+/-1.5 \mathrm{~mm}$ on right and $6.02 \mathrm{~mm}+/-1.6 \mathrm{~mm}$ on left, from PA is $14.9 \mathrm{~mm}+/-2.3 \mathrm{~mm}$ on right and $14.1 \mathrm{~mm}+/-2.4$ on left side and from UAM is about $24.8 \mathrm{~mm}+/-2.9 \mathrm{~mm}$ on right and $21.9 \mathrm{~mm}+/-4.7 \mathrm{~mm}$ on left side. Median value of distance of IOF from IOM is $7 \mathrm{~mm} \& 6 \mathrm{~mm}$, from PA is $14.5 \mathrm{~mm} \& 13 \mathrm{~mm}$, from UAM is $25 \mathrm{~mm} \& 22 \mathrm{~mm}$, on right and left side respectively. Mode value of IOF from IOM is $6 \mathrm{~mm} \& 7 \mathrm{~mm}$, from PA is $14 \mathrm{~mm} \& 13 \mathrm{~mm}$, from UAM is $24 \mathrm{~mm} \& 22 \mathrm{~mm}, 24 \mathrm{~mm}$ on right and left side respectively. Conclusion: Results of the present study may help in Maxillofacial surgeries, Rhinoplasty, Treatment of Trigeminal Neuralgia and Cryotherapy in North Karnataka population.

KEY WORDS: Infra-orbital foramen, Infra-orbital margin, Pyriform aperture, Upper alveolar margin.

Corresponding Author: Dr. Sangeeta. S Patil, Assistant Professor, Mahadevappa Rampure Medical College, Kalaburgi, Gulbarga, Karnataka, India. Ph: $9900537779,7204763456$.

E-Mail: sangeetaspatil19@gmail.com

Access this Article online

Quick Response code

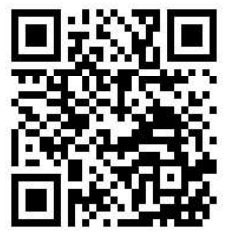

DOI: $10.16965 /$ ijar.2020.126

Journal Information

International Journal of Anatomy and Research

RG Journal ISSN (E) 2321-4287 | ISSN (P) 2321-8967

Impact: 0.21* https://www.ijmhr.org/ijar.htm

DOI-Prefix: https://dx.doi.org/10.16965/ijar

\section{(cc) BT-No-SA}

\section{Article Information}

Received: 17 Feb 2020

Peer Review: 18 Feb 2020

Revised: None
Accepted: 02 Mar 2020

Published (O): 05 Apr 2020

Published (P): 05 Apr 2020

\section{INTRODUCTION}

The orbital surface is marked off from the the facial surface by a ridge of bone which forms the lower and inner half of the orbital opening.
Just below the outer part of this ridge is the the infra- orbital foramen through which the infraorbital branch of the second division of fifth cranial nerve passes to the skin of face [1]. The 

REGION.

infra- orbital foramen can be seen when the skull is viewed from anterior. The infra- orbital foramen, which transmits the infra- orbital vessels and nerve, lies about $1 \mathrm{cms}$ below the infra- orbital margin [2]. The infraorbital artery, branch of maxillary artery enters the orbit through the inferior orbital fissure. It runs on the floor of the orbit in the infraorbital groove and infraorbital canal and emerges onto the face at the infraorbital foramen to supply the lower eyelids, part of the cheek, the side of external nose and upper lip. Within the canal it gives of anterior superior alveolar artery, which runs downwards to supply the anterior teeth and anterior part of maxillary sinus. The infraorbital nerve can be regarded as the terminal branch of the maxillary nerve [2].

It leaves the pterygo- palatine fossa to enter the orbit at inferior orbital fissure. It emerges onto the face at the infraorbital foramen, where it lies between levator labii superioris and levator anguli oris. It gives of palpebral, nasal and superior labial branches. The palpebral branch ascends up to supply the skin of lower eyelid, nasal branches supply the skin of the nose and movable part of nasal septum, superior labial branches which are large and numerous descend to supply the skin of the anterior part of the cheek and upper lip. They are joined by the facial nerve to form the infraorbital plexus. The infraorbital nerve is commonly implicated in trigeminal neuralgia, and is amnenable to cryotherapy where medical therapy fails. Thus, the precise location of Infra- orbital foramen is important not only as acupuncture point used in trigeminal neuralgia treatment but also to locate infra-orbital plexus, which is a risk zone during plastic surgery. It also provides an important data for local anaesthesia during rhinoplasty [3] and maxillofacial surgeries [4]. Presence of accessory infra- orbital foramen's were also encountered during different studies [5]. The present study was conducted to know the precise location of Infra- orbital foramen in dry human skulls in North Karnataka region.

\section{MATERIALS AND METHODS}

Fifty dry adult human skulls of unknown age and sex were examined at the Department of Anatomy (from the departmental collection and $1^{\text {st }}$ MBBS students of 2018- 19 batch),
Mahadevappa Rampure Medical college, Kalaburgi. Both sides of skull were assessed by inspection. Skulls with fractures at piriform aperture, infraobital margin or other destroyed parts affecting the foramen were excluded. Total foramen studied were 100 . The parameters observed and recorded were:

1). The shape of the foramen, Round or Oval.

2). The direction of the foramen.

3). Orientation of the foramen with respect to upper teeth.

4). Distance of IOF from IOM, PA and UAM were recorded as shown in fig: (1) .

5). Diameters of the foramen and presence of accessory foramens recorded.

The measurements were carried out using Vernier calipers. All the values were taken in millimeters $(\mathrm{mm})$. Data collected was subjected to various statistical analysis. The observations from the study are as follows:

Fig. 1: Showing the Measurement procedures.

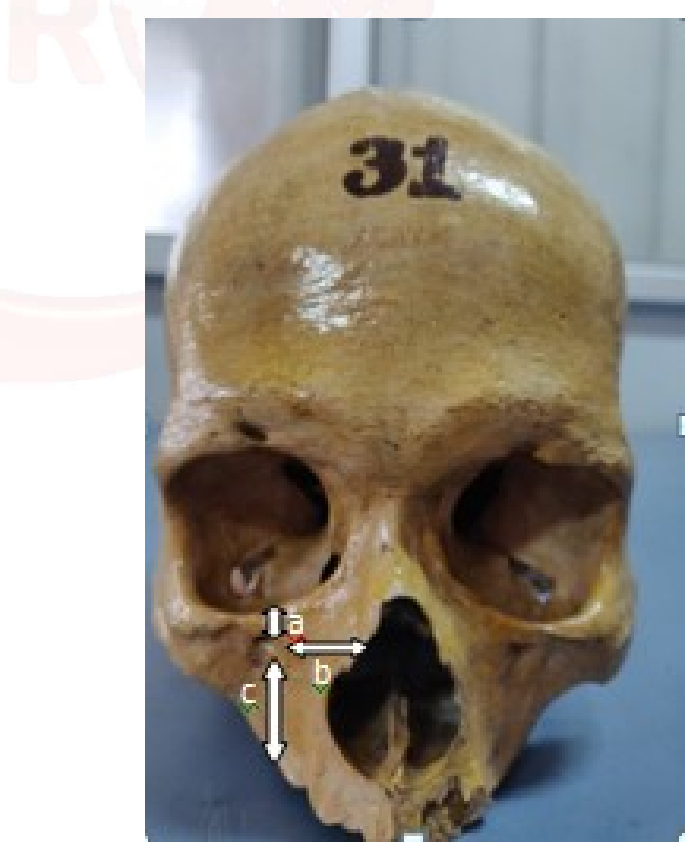

a-IOF-IOM, b- IOF- PA, c- IOF- UAM.

\section{RESULTS}

Fifty adult human skulls, 100 Infra orbital foramen's were examined. The shape, direction, location in relation with teeth, vertical and transverse diameters of the foramen, distance of foramen from infra orbital margin, pyriform aperture and upper alveolar margin were noted and recorded. Measurements were taken using vernier caliper's and analysed statistically. The 
results obtained are as follows:

Majority of IOF's were Oval in shape with total of $62 \%$ - Transversely oval being $26 \%$ \& Vertically oval: $36 \%$ on right side and $64 \%$ - Transversely oval: $22 \%$ \& Vertically oval: $42 \%$ on left side, rest being round in shape with $38 \%$ \& $36 \%$ on right \& left side respectively. Most of the foramen were directed Infero- medially- $76 \%$ on right and $78 \%$ on left side. Rest of them were directed vertically downwards $24 \%$ being on right and $22 \%$ on left side. Orientation of IOF with teeth on right side are $50 \%$ at $2^{\text {nd }}$ premolar , $24 \% \mathrm{~b} / \mathrm{w} 1^{\text {st }} \& 2^{\text {nd }}$ premolar, $10 \%$ b/w $2^{\text {nd }}$ premolar and $1^{\text {st }}$ molar and $16 \%$ at $1^{\text {st }}$ molar and on left side are $46 \%$ at 2 nd premolar, $20 \%$ b/w $1^{\text {st }}$ \& $2^{\text {nd }}$ premolar, $12 \% \mathrm{~b} / \mathrm{w} 2^{\text {nd }}$ premolar and $1^{\text {st }}$ molar and $22 \%$ at $1^{\text {st }}$ molar (Table 1 ).

Foramen's with more vertical diameters ( $36 \%$ on Rt \& $42 \%$ on Lt) were encountered than with transverse diameters ( $26 \%$ on Rt \& $22 \%$ on Lt). Mean value of Vertical diameter on Rt is $3.1 \mathrm{~mm}$ +/- $0.74 \mathrm{~mm}$ SD ( $\min -2 \mathrm{~mm}$ \& max- $4 \mathrm{~mm}$ ) \& on $L t$ is $3.18 m m+/-0.68 m m$ SD (min- $2 m m$ \& max$4 \mathrm{~mm}$ ). Mean value of Transverse diameter is $2.98 \mathrm{~mm}+/-0.73 \mathrm{~mm}$ ( $\min -2 \mathrm{~mm}$ \& max- $4 \mathrm{~mm}$ ) \& $3.02 \mathrm{~mm}+/-0.88 \mathrm{~mm}$ (min- $2 \mathrm{~mm} \& \max -5 \mathrm{~mm}$ ) on right and left respectively (Table 2 ), Median $\&$ Mode value of vertical and transverse diameter on both sides is 3 .

Mean value of distance of IOF from IOM is $6.6 \mathrm{~mm}+/-1.5 \mathrm{~mm}$ on Rt with min distance being $3 \mathrm{~mm}$ and max distance $10 \mathrm{~mm}$ and $6.02 \mathrm{~mm}$ $+/-1.6 \mathrm{~mm}$ on $\mathrm{Lt}$ with min distance $3 \mathrm{~mm}$ and $\max$ $9 \mathrm{~mm}$. Mean value of distance of IOF from PA is $14.9 \mathrm{~mm}+/-2.3 \mathrm{~mm}$ with min distance of $11 \mathrm{~mm}$ and $\max 20 \mathrm{~mm}$ on rt side and $14.1 \mathrm{~mm}+/-2.4$ with min distance of $11 \mathrm{~mm}$ and $\max 19 \mathrm{~mm}$ on It side. Mean value of distance of IOF from UAM is about $24.8 \mathrm{~mm}+/-2.9 \mathrm{~mm}$ with $\mathrm{min}$ value $18 \mathrm{~mm}$ and max value $30 \mathrm{~mm}$ on rt side and $21.9 \mathrm{~mm}+/-4.7 \mathrm{~mm}$ with $\mathrm{min}$ value $12 \mathrm{~mm}$ and max value $31 \mathrm{~mm}$ on $\mathrm{It}$ side. Median value of distance of IOF from IOM is $7 \mathrm{~mm} \& 6 \mathrm{~mm}$, from PA is $14.5 \mathrm{~mm} \& 13 \mathrm{~mm}$, from UAM is $25 \mathrm{~mm} \&$ $22 \mathrm{~mm}$, on rt and It side respectively. Mode value of IOF from IOM is $6 \mathrm{~mm} \& 7 \mathrm{~mm}$, from PA is $14 \mathrm{~mm} \& 13 \mathrm{~mm}$, from UAM is $24 \mathrm{~mm} \& 22 \mathrm{~mm}$, $24 \mathrm{~mm}$ on $\mathrm{rt}$ and $\mathrm{lt}$ side respectively ( Table 3 ). No accessory IOF's were found in the present study.

Int J Anat Res 2020, 8(2.1):7435-39. ISSN 2321-4287
Table 1 : Percentage of Orientation with Teeth.

\begin{tabular}{|l|c|c|}
\hline \multicolumn{1}{|c|}{ Orientation with Teeth } & Right & Left \\
\hline $\mathbf{2}^{\text {nd }}$ premolar & $50 \%$ & $46 \%$ \\
\hline b/w $\mathbf{1}^{\text {st }} \& 2^{\text {nd }}$ premolar & $24 \%$ & $20 \%$ \\
\hline b/w $2^{\text {nd }}$ premolar and $\mathbf{1}^{\text {st }}$ molar & $10 \%$ & $12 \%$ \\
\hline $\mathbf{1}^{\text {st }}$ molar & $16 \%$ & $22 \%$ \\
\hline
\end{tabular}

Table 2: Measurements of IOF.

\begin{tabular}{|c|c|c|c|c|}
\hline \multirow{2}{*}{ Diameters } & \multicolumn{2}{|c|}{$>\%$ of occurance } & \multicolumn{2}{c|}{ Mean +/- SD in $\mathrm{mm}$} \\
\cline { 2 - 5 } & $\mathrm{Rt}$ & $\mathrm{Lt}$ & $\mathrm{Rt}$ & $\mathrm{Lt}$ \\
\hline Vertical & $36 \%$ & $42 \%$ & $\begin{array}{c}3.1+/-0.74 \\
(2 \mathrm{~mm}-4 \mathrm{~mm})\end{array}$ & $\begin{array}{c}3.18+/-0.68 \\
(2 \mathrm{~mm}-4 \mathrm{~mm})\end{array}$ \\
\hline Transverse & $26 \%$ & $22 \%$ & $\begin{array}{c}2.98+/-0.73 \\
(2 \mathrm{~mm}-4 \mathrm{~mm})\end{array}$ & $\begin{array}{c}3.02+/-0.88 \\
(2 \mathrm{~mm}-5 \mathrm{~mm})\end{array}$ \\
\hline
\end{tabular}

Table 3: Statistical Analysis Of Distance of IOF from IOM, PA \& UAM.

\begin{tabular}{|c|c|c|c|c|c|c|}
\hline \multirow{2}{*}{$\begin{array}{c}\text { Distance of IOF } \\
\text { in mm from }\end{array}$} & \multicolumn{2}{|c|}{ Mean +/- SD } & \multicolumn{2}{c|}{ Median } & \multicolumn{2}{c|}{ Mode } \\
\cline { 2 - 8 } & $\mathrm{Rt}$ & $\mathrm{Lt}$ & $\mathrm{Rt}$ & $\mathrm{Lt}$ & $\mathrm{Rt}$ & $\mathrm{Lt}$ \\
\hline IOM & $6.6+/-1.4$ & $6.02+/-1.5$ & 7 & 6 & 6 & 7 \\
\hline PA & $14.9+/-2.3$ & $14.08+/-2.4$ & 14.5 & 13 & 14 & 13 \\
\hline UAM & $24.8+/-2.9$ & $21.9+/-4.7$ & 25 & 22 & 24 & $22.0 \& 24.0$ \\
\hline
\end{tabular}

\section{DISCUSSION}

Maxilla consist of a hollow body, zygomatic, frontal, alveolar and palatine processes. The body on its anterior surface shows ridges, just below its infra orbital margin, the infra orbital foramen transmits infra orbital vessels and nerve [6]. Therefore the knowledge of its location is very essential for surgeons and anesthetists. Very few studies have been conducted on North Karnataka population, thus the data available is very scanty. Present study was conducted on skulls of North Karnataka population, which forms a source of information for surgeons treating the population of the particular area, whether residing here or anywhere in the world. The data recorded were Mean+/- standard deviation (Mean, the average value \& SD provides variability of the foramen around Mean value), Median (middle value of the data), Mode (value which appears often in the data collected) [Table 3].

The study conducted on 100 adult dried human skulls of both sexes of Bhopal region on Infra orbital foramen, found majority were oval in shape (54.6\% in males \& $52.8 \%$ in females), most of them were directed inferomedially (65.8\% in males \& $67.8 \%$ in females), majority of them were oriented to $2^{\text {nd }}$ premolar teeth, 

REGION.

mean distance of infra orbital foramen to infra orbital margin was $7.43 \mathrm{~mm}+/-1.68$ (R), $7.37 \mathrm{~mm}+/-1.59$ (L)and accessory foramen were noticed in $4 \%$ skulls [7].

Study of 60 dried human skulls of unknown age, sex and race on Infra orbital foramen noted that, the Mean distance of Infra orbital foamen with Infra orbital margin was $6.67+/-2.10 \mathrm{~mm}$ $(\mathrm{R}), 6.90+/-1.84(\mathrm{~L})$, commonest location being $2^{\text {nd }}$ premolar and direction being inferomedial(8), Almost nearing to the values of present study.

100 human dry macerated skulls of Maharastra regione were studied and found the Mean distance between infra orbital foramen and Infra orbital margin was $6.54+/-1.28 \mathrm{~mm}(\mathrm{R})$, $7.02+/-1.42 \mathrm{~mm}(\mathrm{~L})$, Mean distance between Infra orbital foramen and pyriform aperture was $16.20+/-2.72 \mathrm{~mm}(\mathrm{R}), 15.82+/-2.75(\mathrm{~L})$. Mean distance between Infra orbital foramen and Upper Alveolar margin was $28.93+/-4.11 \mathrm{~mm}(\mathrm{R})$, 28.42+/-4.43mm(L).

Mean vertical diameter of the foramen on right was $3.23+/-0.76 \mathrm{~mm}$ and on left was $3.25+/-$ $1.03 \mathrm{~mm}$ [ Present study-3.1+/-0.74mm(R),3.18+/ $-0.68 \mathrm{~mm}(\mathrm{~L})]$, the Mean horizontal diameter being $3.0+/-0.76$ on right and $3.28+/-0.99 \mathrm{~mm}$ on left [Present study-2.98+/-0.73mm (R),3.02+/ $-0.88(L)]$, majority were directed inferomedially [9]. The study on 47 cadavers, found Mean distance between infra orbital foramen and infra orbital rim to be $8.5+/-2.2 \mathrm{~mm}$ in males and $7.8+/-1.6 \mathrm{~mm}$ in females [4].

Table 4: Comparison of mean values and standard deviation with different authors.

\begin{tabular}{|c|c|c|c|c|c|c|c|}
\hline \multirow{2}{*}{ Study } & \multirow{2}{*}{ Size } & \multicolumn{2}{|c|}{ IOF-IOM } & \multicolumn{2}{c|}{ IOF- PA } & \multicolumn{2}{c|}{ IOF- UAM } \\
\cline { 3 - 8 } & & RT & LT & RT & LT & RT & LT \\
\hline Present & 100 & $6.6+/-1.4$ & $6.02+/-1.5$ & $14.9+/-2.3$ & $14.08+/-2.4$ & $24.8+/-2.9$ & $21.9+/-4.7$ \\
\hline K K Gour [7] & 200 & $7.43+/-1.68$ & $7.37+/-1.59$ & & & & \\
\hline $\begin{array}{c}\text { Janghu Poonam } \\
\text { Kharb [8] }\end{array}$ & 120 & $6.67+/-2.10$ & $6.90+/-1.84$ & & & & \\
\hline Amrita Bharti [9] & 200 & $6.54+/-1.28$ & $7.02+/-1.42$ & $16.20+/-2.72$ & $15.82+/-2.75$ & $28.93+/-4.11$ & $28.42+/-4.43$ \\
\hline Macedo VC [10] & 590 & $6.28+/-1.79$ & $6.45+/-1.76$ & $17.75+/-2.10$ & $17.60+/-2.04$ & & \\
\hline Rajani Singh [11] & 110 & $6.12+/-1.79$ & $6.19+/-1.81$ & $15.31+/-1.77$ & $15.80+/-2.86$ & & \\
\hline
\end{tabular}

\section{CONCLUSION}

The present study was done on the skulls of North Karnataka population and precise location
The study on 590 IOF's Mean distance between infra orbital foramen and Infra orbital margin was $6.28+/-1.79 \mathrm{~mm}(\mathrm{R}), 6.45+/-1.76 \mathrm{~mm}(\mathrm{~L})$. Mean distance between Infra orbital foramen and pyriform aperture was17.75+/-2.0 $\mathrm{mm}(\mathrm{R})$, $17.60+/-2.04$ (L) [10].

The study conducted on 110 IOF's show Mean distance between infra orbital foramen and Infra orbital margin to be $6.12+/-1.79 \mathrm{~mm}(\mathrm{R}), 6$. $12+/-1.81 \mathrm{~mm}(\mathrm{~L})$ Mean distance between Infra orbital foramen and pyriform aperture was $15.31+/-1.77 \mathrm{~mm}(\mathrm{R}), 15.80+/-2.86 \mathrm{~mm}(\mathrm{~L})$. Mean vertical diameter of the foramen on right was $3.39+/-0.96 \mathrm{~mm}$ and on left was $3.75+/-1.07 \mathrm{~mm}$, the Mean horizontal diameter being 3.19+/-1.19 on right and $3.52+/-1.35 \mathrm{~mm}$ on left [11].

Our present study also shows similar results, oval foramen's being most common, directed inferomedially and oriented to $2^{\text {nd }}$ premolar (Table 1). Comparison of mean values of distances of IOF and IOM, PA and UAM of present study with other studies is shown in Table 4.

Study of 11 cadavaric skulls was done to know the anatomy of infra orbital canal and foramen as a guide for determining the angles at which Radiofrequency probe must be directed for the radiofrequency ablation of infra orbital nerve for the patients with relative or absolute contraindications to lesions of trigeminal neuralgia [12]. and morphometry of Infra- orbital foramen measured and subjected to various statistical analysis. It is important to know morphometry 
and precise location of IOF, not only as acupuncture point used in trigeminal neuralgia treatment but also to locate infra-orbital plexus, which is a risk zone during plastic surgery. It also provides an important data for local anaesthesia during rhinoplasty, maxillofacial surgeries. Thus, the present study provides a source of information for surgeons treating the population of the North Karnataka region, whether residing here or anywhere in the world.

\section{ABBREVATION}

IOF- Infra- Orbital Foramen

IOM- Infra Orbital Margin

PA- Pyriform Aperture

UAM- Upper Alveolar Margin

\section{Conflicts of Interests: None}

\section{REFERENCES}

[1]. Carl C Francis. The Skeleton. Introduction to human anatomy. $4^{\text {th }}$ Ed. Saint Louis The C.V. Mosby Company. 1964: pg 73.

[2]. Susan Standring. External Skull. Gray's anatomy: The Anatomical Basis Of Clinical Practice. $40^{\text {th }} \mathrm{Ed}$. Elsevier Churchill Livingstone, Spain. 2008: pg 409.

[3]. Zide BM, Swift R. How to block and tackle the face. Plast Reconstr Surg 1998; 101: 840-51.

[4]. Shahid R Aziz, Jose M Marchena Anita Puran. Anatomic characteristics of the infraorbital foramen: a cadaveric study. J Oral Maxillofac Sur 2000; 58(9): 992-96.
[5]. Tezer M, Ozturk A, Akgul M, Gaytreli O and Kale A. Anatomic and morphometric features of the accessory infraorbital foramen. J. Morphol. Sci 2011; 28(2): 95-97.

[6]. RD Lockhart, GF Hamilton, FW Fyfe. Bones and Joints. Anatomy of The Human Body. Faber \& Faber limited,London. 1959: pg 45.

[7]. K K Gour, S Nair, G N Trivedi, S D Gupta: Anthropometric Measurements Of Infra Orbital Foramen in dried human skulls. International Journal of Biological \& Medical Research. 2012; 3(3): 2003- 2006.

[8]. Janghu Poonam Kharb, Samanta Prajna P, Gupta Nirupama: Morphometric Analysis of Infra Orbital Foramen In Dry Adult Skulls And Its Surgical Relevence. Journal Of Advance Researches in Biological Sciences. 2012; Vol 4 (2): 83- 87.

[9]. Dr. Amrita Bharti and Dr Megha G Puranik: Morphomteric Study Of Infraorbital Foramen In Dry Human Skulls. National Journal Of Integrated Research in Medicine . 2013; Vol 4(3): 43- 49.

[10]. Macedo VC, Cabrini RR and Faig- Leite H: Infraorbital foramen location in dry human skulls. Braz J. Morphol. Sci. 2009; vol 26(1): 35-38.

[11]. Rajani Singh. Morphometric analysis of infraorbital foramen in Indian dry skulls. Anatomy \& Cell Biology. 2011; 44: 79-83.

[12]. Rahman M, Richter EO, Osawa S and Rhoton Al Jr: Anatomic study of the infraorbital foramen for the radiofrequency neurotomy of the infraorbital nerve. Neurosurgery. 2009 May; 64 (5 Suppl 2): 423- 27.

How to cite this article:

Archana N Kotli, Sangeeta S Patil. MORPHOMETRIC ANALYSIS OF INFRA- ORBITAL FORAMEN IN DRY HUMAN SKULLS IN NORTH KARNATAKA REGION. Int J Anat Res 2020;8(2.1):7435-7439. DOI: 10.16965/ijar.2020.126 